\title{
RESOURCE USE EFFICIENCY ANALYSIS IN STRAWBERRY PRODUCTION IN SELECTED AREAS OF BANGLADESH
}

\author{
M. Khatun ${ }^{1 *}$, M.A. Rashid ${ }^{1}$, S. Khandoker ${ }^{1}$, N.D. Kundu ${ }^{2}$ and M.A. Matin ${ }^{1}$ \\ ${ }^{1}$ Agricultural Economics Division, Bangladesh Agricultural Research Institute, Joydebpur, Gazipur, \\ ${ }^{2}$ Regional Pulses Research Center, Madaripur, Bangladesh
}

\begin{abstract}
Inefficient use of existing scarce resources has adverse effect on food production and production cost hence, low income among the farmers across the nation. Strawberry farming is profitable but costly. So the study was designed to explore resource use efficiency of strawberry cultivation in Rajshahi and Joypurhat district of Bangladesh. Primary data were collected from 100 strawberry growing farmers. Data were analyzed by using descriptive statistics, Cobb-Douglass production function and marginal productivity analysis. The results showed that $41 \%$ farmers were 18 to 30 years old. Highest $26 \%$ farmers had primary level of education, $61 \%$ farmers had small farm, and $69 \%$ farmers had 1 to 3 years' experience of strawberry cultivation. The double log function showed the best fit with adjusted $\mathrm{R}^{2}$ of $61 \%$. Production inputs such as sapling and fertilizer had positive and labour and chemicals had negative and significant effect on outputs. Sapling, land and water were underutilized and labour, cowdung, fertilizer and chemicals were over used. About $37 \%$ farmers reported that strawberry plants were attacked by many more diseases. Approximately, $48 \%$ farmers reported that transportation facilities of the study areas were poor. Efficiency ratio of the inputs indicates, farmers of the study area were not efficient in using inputs and it is needed to adjust resource use in order to improve farm profit at this level of technology used. The study also recommends that the farmers need training to be efficient.
\end{abstract}

Keywords: Cob-Douglas Production Function, Efficiency, MFC, MVP, Resource use, Strawberry

\section{INTRODUCTION}

Strawberry is a tasty and nutritious fruit which is popular for its attractive colour, aroma and sweetness. It is a significant cold loving fruit, grown throughout the world. USA, Spain, Japan, Poland, Korea and Russian Federation are the key strawberry producing countries of the world. A cup of strawberries provides 55

*Corresponding Author: morsalinak@gmail.com 
calories and vitamin $\mathrm{C}$ content is more than the recommended human daily requirement (Salami et al., 2010). For producing sufficient berries for an averagesized family, 25-50 strawberry plants are enough (Dickerson, 2004). Strawberry (Fragariax ananassa Duchesne) fruits are commonly consumed in fresh forms, as processed food products, and as botanical extracts for dietary supplements. Strawberry juice extracts be full of high levels of antioxidant which works against superoxide radicals, hydrogen peroxide, hydroxyl radicals, and singlet oxygen free radicals. It also has the total antioxidant capacity for low-density lipoproteins of the fruit extracts (Salami et al., 2010).

In Bangladesh, it is new crop grown commercially in few district such as Tangail, Rajshahi, Joypurhat, Bogra, Kumilla, Sathkhira, Khagrachari and Coxbazar. It has a great significance as it is grown in winter season when our native fruits are rare. In this time, strawberry can play an important role by meeting nutrition of mass people. Strawberry cultivation is also considered as a profitable crop grown to the farmers but it is not enough accepted to Bangladeshi farmers due to its huge cost association. Besides, strawberry is a highly perishable fruit and the farmers do not have any training on its production and handling technique. Consequently, they take intensive care of it and to do so sometimes they over used their resources. Agricultural economists always offer the direction of efficient utilization of inputs to the farmers. Efficient utilization of inputs has significant impacts on food security (Chiedozie et al., 2010). Resource use efficiency investigates the efficiency of each input and indicates the overutilization or underutilization of inputs (Ali et al., 2017). So it is essential to evaluate efficiency level of the farmers in case of input use as the aim of any profitable farm is to maximize profit by minimizing cost. Therefore, the study was designed with the following objectives: 1) to examine the socioeconomic characteristics of strawberry farmers; 2) to estimate input-output relationship of strawberry production; 3 ) to assess the resource use efficiency of strawberry growers and 4) to identify the production problems, and marketing constraints of strawberry cultivation.

Several literatures are accessible about the estimation of resource use efficiency for different agricultural crops except strawberry (Majumder et al., 2009; Islam et al., 2011; Rahman, 2011; Ahmed et al., 2015; Bapari, 2016; Sujan et al., 2017a; Sujan et al., 2017b; Sarker et al., 2018). Goni et al. (2013) investigated the efficiency of resource use in the production of dry season vegetables in Nigeria. They stated farmers were inefficient in the utilization of all resources because of under-utilization (seed, pesticide and land) and over-utilization (fertilizer, herbicide and labour). They mentioned if farmers increase the use of seed, pesticide and land, vegetable output will be increased by $114.58,322.64$ and $568.72 \mathrm{~kg} \mathrm{ha}^{-1}$, respectively. Similarly, Shrestha et al. (2015) estimated the efficiency of resource use in the production of vegetables in Nepal. The value of technical efficiency (0.79) pointed out toward the possibility of increase in the production of vegetable by efficient utilization of resources (land, seeds, labour, fertilizers, compost, farm capital and pesticides) while 
technology remains constant. They suggested for improvement in land, labour, training, and easy capital access. Miah et al. (2006) explored the resource use efficiency of credit users and non-credit users in modern variety of boro rice production. They showed that both types of farmers did not use inputs efficiently. Non-borrowers under-utilized human labour, tillage, manure, fertilizer and pesticides and over used seeds and irrigation. Borrowers paid out less money on the use of seed or seedling, manure, fertilizer, pesticide and human labour and more money on tillage and irrigation. Khandoker et al. (2014) studied resource use efficiency of commercial floriculture in Bangladesh. They found positive and significant effect of power tiller, seedling and chemical fertilizer on floriculture. They also mentioned flower cultivator allocated their resources in the first stage of production where increasing returns to scale prevail.

But, resource use efficiency in strawberry production was still not studied in Bangladesh. For this reason this study was conducted.

\section{MATERIALS AND METHODS}

The study was mainly based on primary data that were collected through face to face interview using a pre-tested interview schedule which was conducted through field survey during the month of December, 2016 to March, 2017. Rajshahi and Joypurhat district was the pioneer of strawberry cultivation. At present strawberry is being cultivated by the farmers of Tangail, Kumilla, Sathkhira, Khagrachari and Coxbazar in scattered way but in Rajshahi and Joypurhat a good number of farmers are cultivating strawberry. So, Rajshahi and Joypurhat were selected for this study.

\section{Sampling technique and sample size}

Multistage sampling technique was followed to collect sample farmers for this study. At first, two districts namely Joypurhat and Rajshahi were selected on the basis of availability of strawberry farmer. In the second stage, concentrate strawberry growing upazila from each district were selected on the basis of area and production of strawberry. Sadreupazila from Joypurhat and Charghatupazila from Rajshahi were selected. Thirdly, 2-3 agricultural Blocks were selected in consultation with DAE personnel for selecting sample farmers. Finally, the samples were randomly selected from the complete list of strawberry farmers for interview. Mari (2009) and Ali et al, (2017) stated that 60 sample was appropriate for decision making in case of large population. However, a total of 100 strawberry growers taking 50 farmers from each district were selected for the study. Open source software R, Microsoft Excel and STATA-10 were used for analyzing results.

\section{Production function and its stages}

Production function is a functional relationship between output and inputs (Jhingan, 2007). There are three stages of production. MPP is negative in stage III and it is not rational to produce with negative MPP (Akighir and Shabu, 2011). 


\section{Model Specification}

The Cobb-Douglas production model was useful for the estimation of resource use efficiency due to econometric and statistical advantages like sign and size of coefficients, t-test, f-test and $\mathrm{R}^{2}$ (Ashfaq et al., 2012).It was also used in many studies (Abid et al., 2011; Ali et al., 2017; Khatun et al., 2017; Ibitoye et al., 2015; Umar and Abdulkadir, 2015). The double-log function (Cobb-Douglas) provided the best fit and was therefore chosen for the study (Olomla, 1991; Mbata et al., 1993).

Using the ordinary least square (OLS) estimator, the production response function model was expressed implicitly as:

$\mathrm{Y}=\mathrm{f}\left(\mathrm{X}_{1}, \mathrm{X}_{2}, \mathrm{X}_{3}, \mathrm{X}_{4}, \mathrm{X}_{5}, \mathrm{X}_{6}, \mathrm{X}_{7}, \mathrm{Ui}\right)$

Where

$\mathrm{Y}=$ quantity of output in kilograms,

$\mathrm{X}_{1}=$ labour(man-days),

$\mathrm{X}_{2}=$ no. of sapling,

$\mathrm{X}_{3}=$ quantity of cowdung in kilograms,

$\mathrm{X}_{4}=$ quantity of fertilizer in kilograms,

$\mathrm{X}_{5}=$ land (farm size),

$\mathrm{X}_{6}=$ quantity of water in liter and

$\mathrm{X}_{7}=$ quantity of chemicals in kilograms.

The functional form of the double-log function was ex-pressed as follows:

$\ln \mathrm{Y}=\mathrm{b}_{0}+\mathrm{b}_{1} \ln \mathrm{X}_{1}+\mathrm{b}_{2} \ln \mathrm{X}_{2}+$ $+\mathrm{b}_{7} \ln \mathrm{X}_{7}+\mathrm{e}$

\section{Resource use Efficiency}

It is a ratio between Marginal Value Product (MVP) for a specific input and Marginal Factor Cost (MFC) of that particular input (Abid et al. 2011; Ashfaq et al. 2012;

Mohammed et al. 2014; Umar and Abdulkadir, 2015; Ali et al. 2017) as:

$\mathrm{r}_{\mathrm{i}}=\mathrm{MVP}_{\mathrm{i}} / \mathrm{MFC}_{\mathrm{i}}$

where:

$r_{i}=$ Resource use efficiency ratio

$\mathrm{MVP}_{\mathrm{i}}=$ Value of additional output by using an additional unit of a particular input resource

$\mathrm{MVP}_{\mathrm{i}}=\mathrm{MPP}_{\mathrm{i}} \times \mathrm{Py}$

$\mathrm{MFC}_{\mathrm{i}}=\mathrm{PX}_{\mathrm{i}}=\mathrm{It}$ is price of one unit of input resource.

Where, $\mathrm{Py}$ and $\mathrm{MFC}_{\mathrm{i}}$, are the unit prices of output and factor input respectively.

The marginal physical product (MPP) was given by: $\mathrm{MPP}_{\mathrm{i}}=\mathrm{b}_{\mathrm{i}} \times \mathrm{APP}_{\mathrm{i}}$ 
Where $b_{i}=$ elasticity's of the various inputs

$\mathrm{APP}_{\mathrm{i}}=\frac{\bar{Y}}{\overline{X_{i}}}$

Where

$\overline{\mathrm{Y}}$ is the mean of output and $\overline{X_{i}}$ is the mean of factor inputs and bi are the regression coefficients.

The decision of whether a resource is used efficiently or not, thus efficiency, is based on the value of $r_{i}$, Ifr $r_{i}$ is equal to one $\left(r_{i}=1\right)$, then the factor input is efficiently utilized. The factor input is over-utilized if $r_{i}$ is less than $1\left(r_{i}<1\right)$ and under-utilized if $r_{i}$ is greater than unity $\left(r_{i}>1\right)$. The relative percentage change in MVP of each resource required so as to obtain optimal resource allocation, which is $r=1$ or MVP $=\mathrm{MFC}$, was estimated using equation 7 below:

$\mathrm{D}=(1-\mathrm{MFC} / \mathrm{MVP}) \mathrm{X} 100=(1-\mathrm{r}-1) \times 100$

$=(1-1 / \mathrm{r}) \mathrm{x} 100$

Where:

$\mathrm{D}=$ absolute value of percentage change in MVP of each resource (Mijindadi 1980; Gani and Omonona 2009; Chandra et al. 2017). The significance of each explanatory variable was determined using the t-test. The overall significance was determined by the F-ration.

\section{RESULTS AND DISCUSSION}

\section{Farmers' profile}

Age: Age is an important factor that influences farmer's production decision, efficiency and managing the capital used in farming. Strawberry is a new crop in Bangladesh and comparatively young farmers (minimum age 18 years) were cultivating it. Majority of the strawberry farmers $(41 \%)$ were 18 to 30 years old (Table 1). Mean age of the strawberry farmers was 36.52 years. Other farmers were belonging to the age group of 31 to 43 years (32\%), 44 to 56 years (17\%), 57 to 69 years $(8 \%)$ and 70 to 82 years $(2 \%)$. Maximum age of the farmers was 74 years and standard deviation was 13.30 .

Literacy status: The sample farmers were classified into six categories based on their education level. Table 1 indicates that literacy status of the strawberry farmers were better in position. Only $4 \%$ farmers were illiterate. Highest $26 \%$ farmers had primary level of education. Number of farmers having higher secondary level of education was $11 \%$ and degree and above level education was $21 \%$. About $19 \%$ farmers had secondary level of education and another $19 \%$ farmers can sign only. 
Table 1. Profile of the respondent farmers in the study areas

\begin{tabular}{|c|c|c|c|c|c|c|}
\hline Particulars & Freq. & $\%$ & Min. & Max. & Mean & Std. dev \\
\hline 1. Age & & & 18 & 74 & 36.52 & 13.30 \\
\hline $18-30$ years & 41 & 41 & & & & \\
\hline $31-43$ years & 32 & 32 & & & & \\
\hline $44-56$ years & 17 & 17 & & & & \\
\hline 57-69 years & 8 & 8 & & & & \\
\hline $70-82$ years & 2 & 2 & & & & \\
\hline \multicolumn{7}{|l|}{ 2. Literacy status } \\
\hline Illiterate & 4 & 4 & & & & \\
\hline Can sign & 19 & 19 & & & & \\
\hline Primary (Class I-V) & 26 & 26 & & & & \\
\hline Secondary (Class VI-X) & 19 & 19 & & & & \\
\hline Higher secondary (HSC) & 11 & 11 & & & & \\
\hline Degree and above & 21 & 21 & & & & \\
\hline \multicolumn{7}{|l|}{ 3. Occupation } \\
\hline \multicolumn{7}{|l|}{ Main occupation } \\
\hline Agriculture & 70 & 70 & & & & \\
\hline Student & 20 & 20 & & & & \\
\hline Business & 6 & 6 & & & & \\
\hline Service & 2 & 2 & & & & \\
\hline Other & 2 & 2 & & & & \\
\hline \multicolumn{7}{|l|}{ Subsidiary occupation } \\
\hline No profession & 54 & 54 & & & & \\
\hline Agriculture & 31 & 31 & & & & \\
\hline Business & 15 & 15 & & & & \\
\hline 4. Farm size (ha) & & & 0.07 & 4.90 & 0.71 & 0.67 \\
\hline Marginal (below 0.19 ha) & 16 & 16 & & & & \\
\hline Small (0.19-0.99 ha) & 61 & 61 & & & & \\
\hline Medium (1.00-3.03 ha) & 22 & 22 & & & & \\
\hline Large (above 3.03 ha) & 1 & 1 & & & & \\
\hline 5. Experience & & & 1 & 8 & 2.94 & 1.14 \\
\hline $1-3$ & 69 & 69 & & & & \\
\hline $4-6$ & 30 & 30 & & & & \\
\hline $7-9$ & 1 & 1 & & & & \\
\hline
\end{tabular}


Occupational status: A good number of respondent farmers have both main and subsidiary occupation. Main occupation of a farmer generally reflects his commitment in that particular field and demonstrates his economic standing in the society. Majority of the farmers $(70 \%)$ main occupation was agriculture (Table 1$)$. In the study areas main occupation of few farmers were business $(6 \%)$, service $(2 \%)$ and others $(2 \%)$. More than half of the farmers $(54 \%)$ had no subsidiary occupation. About $31 \%$ farmers had agriculture and $15 \%$ farmer had business as their subsidiary occupation.

Farm size: Farm size of most of the farmers $(61 \%)$ was small. In the study areas lowest farm size was found 0.07 ha. Average land holdings of the farmers were estimated 0.71 ha. Farm size was medium and marginal reported by $22 \%$ and $16 \%$ farmers respectively. Only $1 \%$ farmers had large farm size which is 4.90 ha and standard deviation was 0.67 .

Farmers' experiences: Highest strawberry cultivation experience of the farmers was found 8 years. Mean experience of strawberry farming was 2.94 years. About $69 \%$ of the farmers had 1 to 3 years' experience. A good percentage of farmers $(30 \%)$ had also experiences with in the year ranged from 4 to 6 years (Table 1). Minimum experience was only 1 year and standard deviation was 1.14 .

\section{Estimated production function and resource use efficiency}

Results of the production function indicate output was positively related to sapling, Cow dung, fertilizer, land (farm size) and water. This implies that output increased with the increase of the quantities of those inputs. On the other hand output was negatively related to labour and chemicals (insecticides, pesticides and fungicides). This implies that output increased with the increase of the quantities of those inputs. The value of the coefficient of determination $\left(\mathrm{R}^{2}\right)$ was 0.611 which indicated that around $61 \%$ of the variation in output was explained by the independent variables included in the model (Table 2). The value of $F$ was 1.931 which was significant at $5 \%$ level indicates the good fit of the model. The total elasticity (sum of the partial elasticity 0.456) showed decreasing returns to scale implies that when all other variables are held constant, a unit increase in one of them results in less than proportionate increase in output. 
Table 2. Estimated value of coefficients and related statistics of Cobb-Douglas production function

\begin{tabular}{lccc}
\hline \multicolumn{4}{c}{ Dependent Variable: LNOUTPUT } \\
\hline \multicolumn{4}{c}{ Included observations: 100} \\
\hline Variable & Coefficient & Std.Error & t-statistic \\
Labour & $-0.0094^{*}$ & 0.004 & -1.92 \\
Sapling & $0.3187^{* * *}$ & 0.170 & 3.20 \\
Cowdung & 0.0068 & 0.0072 & 0.94 \\
Fertilizer & $0.0715^{*}$ & 0.038 & 1.86 \\
Land & 0.067 & 0.110 & 0.609 \\
Water & 0.0057 & 0.0037 & 1.53 \\
Chemicals & $-0.0043^{* * *}$ & 0.0016 & -2.620 \\
Constant & $6.128^{* * *}$ & 1.073 & 5.71 \\
R-squared & & 0.611 & \\
F-ratio & & $1.931^{* *}$ & \\
Returns to scale $\left(\mathrm{b}_{1+} \mathrm{b}_{2+} \mathrm{b}_{3+} \mathrm{b}_{4+} \mathrm{b}_{5}+\mathrm{b}_{6}+\mathrm{b}_{7}\right.$ & & 0.456 & \\
\hline
\end{tabular}

Note: $* * *, * *$ and $*$ indicate significant at $1 \%$ and $5 \%$ and $10 \%$ level respectively

Table 3 shows that the ratios of MVP and MFC are greater than unity for sapling, land, and water indicating that such inputs were underutilized. Farmers in the study area used too little of these inputs to cultivate strawberry that means the cost of using these inputs is less than the value of marginal product. This suggests that farmers can incur more cost for these inputs to be efficient. For key variable, labour, cow dung, fertilizer and chemicals comparison of the ratio of MVP to MFC revealed a resulting ratio to be less than unity implying that such inputs were over utilized. This suggests that farmers can deduct the use of the amount of these inputs to be efficient. In both cases all the inputs were not optimally utilized.

Table 3. Estimated resource use efficiency in strawberry production

\begin{tabular}{l|c|c|c|c|c|c|c}
\hline Variable & Coefficients & MPP & Py & MVP & MFC & MVP/MFC & $\begin{array}{c}\text { Adjustment } \\
\text { required (\%) }\end{array}$ \\
\hline Labour & -0.0094 & -0.1487 & 104.56 & -15.5498 & 300 & -0.0518 & 2031 \\
Sapling & 0.3187 & 0.1945 & 104.56 & 20.341 & 8 & 2.5426 & 61 \\
Cowdung & 0.0068 & 0.0117 & 104.56 & 1.2192 & 1.55 & 0.7865 & 27 \\
Fertilizer & 0.0715 & 0.0437 & 104.56 & 4.5655 & 35.95 & 0.1270 & 687 \\
Land & 0.067 & 1962.82 & 104.56 & 205232.1 & 31486 & 6.5182 & 85 \\
Water & 0.0057 & 0.00029 & 104.56 & 0.0307 & 0.022 & 1.3941 & 28 \\
Chemicals & -0.0043 & -15.55 & 104.56 & -1626.41 & 400 & -4.0660 & 125 \\
\hline
\end{tabular}


The adjustment in the MVPs for optimal resource use indicated that for optimal allocation of inputs their level of use should be increased or decreased. Human labor was needed to decrease by $20-31 \%$ to obtain the optimum profit. Similarly, the level of use of cowdung, fertilizer and chemical should be decreased by $27 \%, 687 \%$ and $125 \%$ respectively. On the other hand, for optimal allocation of sapling, land, and water, their level of use should be increased by $61 \%, 85 \%$ and $28 \%$ respectively (Table 3).

\section{Production problems faced by the farmers}

Though strawberry has a good potentialities, farmers in the study areas faced some problems to produce strawberry because they had no training on strawberry cultivation. Highest $37 \%$ farmers reported that strawberry plants were attacked by many more diseases. About $30.5 \%$ farmers reported that they faced the problem of quality sapling in time. $28 \%$ farmers reported that their plant was dying (Table 4). Since more capital was required in strawberry production, $13 \%$ farmers in the study areas faced the problem of capital. $12 \%$ farmers reported that they had no adequate knowledge about strawberry cultivation practices. They also faced the problem of fruit damage (9\%), attack of birds (7\%) and insect pest (4\%), plant damage (4\%) and scarcity of labour $(2 \%)$.

Table 4. Problems faced by the farmer in producing strawberry in the study areas

\begin{tabular}{l|c|c|c}
\hline \multirow{2}{*}{\multicolumn{1}{c|}{ Problems }} & \multicolumn{3}{c}{ \% farmers responded } \\
\cline { 2 - 4 } & Joypurhat & Rajshahi & All areas \\
\hline More disease presence in strawberry plant & 38 & 36 & 37 \\
Lack of quality sapling in proper time & 18 & 34 & 30.5 \\
Plant is dying & 36 & 20 & 28 \\
Lack of capital & 16 & 10 & 13 \\
Lack of knowledge about strawberry cultivation & 20 & 4 & 12 \\
Fruits damage due to raining & 8 & 10 & 9 \\
High price of sapling & 4 & 12 & 8 \\
Attack of birds & - & 14 & 7 \\
Attack of insect & - & 8 & 4 \\
Production of sapling is so difficult & 6 & 2 & 4 \\
Requirement of insecticide is high & 4 & 4 & 4 \\
Damage of plant due to fog & 4 & 4 & 4 \\
Lack of labour & 2 & - & 1 \\
\hline
\end{tabular}




\section{Marketing constraints faced by the farmers}

In the study areas there was no marketing system of strawberry, so they faced problems to market their product. $48 \%$ farmers reported that transportation facilities of the study areas were poor. Farmers (24\%) could not sell their product without Arath, commission of the Arathder was high (23\%). Therefore, they did not get fair price $(16 \%)$ (Table 5). On an average $9 \%$ farmers reported that in local market there was no demand for strawberry. As a result, when unrest situation prevail in the country, farmers lost their whole amount of strawberry. They also mentioned there was no cold storage facility (6\%) and transportation cost was high (2\%).

Table5. Marketing Problems faced by the farmer in the study areas

\begin{tabular}{l|c|c|c}
\hline \multicolumn{1}{c}{ Problems } & Joypurhat (\%) & Rajshahi (\%) & All areas (\%) \\
\hline Poor transportation facilities & 50 & 46 & 48 \\
Do not sell without Arath & 30 & 18 & 24 \\
Commission of Arathdar is high & 16 & 30 & 23 \\
Do not get fair price & 8 & 24 & 16 \\
There is no specific strawberry market & - & 12 & 12 \\
There is no demand in local market & 12 & 6 & 9 \\
There is no cold storage facility & 10 & 2 & 6 \\
High transportation cost & 2 & 2 & 2 \\
\hline
\end{tabular}

\section{CONCLUSION}

A large number of people, mostly unemployed youths, were engaged on strawberry farming. It was observed that labour, sapling, fertilizer and chemicals had significant effect on strawberry production. As strawberry cultivation is new in Bangladesh, farmers have no scientific knowledge about its production technology. They were not efficient in using inputs, they used excessive amount of several resources like labour, cow dung, fertilizer and chemicals and under used sapling, land and water to produce strawberry. Farmers in the study area faced some problems to produce strawberry because they have no training on strawberry cultivation.

To ensure efficient use of resources training on production technology should be given to the farmers. To control disease presence in strawberry, plant pathologist should undertake research on it. To reduce the use of chemicals, Entomologist should undertake research to control insect. To make sapling of BARI variety available in the farmers' field, Pomology division, HRC, BARI should produce and disseminate it to the farmers. If done so, production of strawberry will be increased, import will be decreased and foreign currency will be saved. 


\section{REFERENCES}

Abid, M., Ashfaq, M., Quddus, M.A., Tahirand, M.A., and Fatima, N. (2011). A resource use efficiency analysis of small Bt cotton farmers in Punjab, Pakistan. Pakistan Journal of Agricultural Science, 48: 75-81.

Ahmed, M.T., Nath, S.C., Sorwar, S.S.R.M.M.A., and Rashid, M.H. (2015). Costeffectiveness and resource use efficiency of sweet potato in Bangladesh. Journal of Agricultural Economics and Rural Development, 2(2): 026-031.

Akighir, D.T., and Shabu, T. (2011). Efficiency of resource use in rice farming enterprise in Kwande local government area of Benue state, Nigeria. International Journal of Humanities and Social Science, 1: 215-220.

Ali, Q., Asfaq, M., and Khan, M.T.I. (2017). Resource use efficiency and return to scale analysis in off-season cucumber production in punjab, pakistan. Sarhad Journal of Agriculture, 33(1): 47-52.

Ashfaq, M.M., Abid, K.B., and Fatima, N. (2012). Analysis of resource use efficiencies and return to scale of medium sized Bt cotton farmers in Punjab, Pakistan. Sarhad Journal of Agriculture, 28: 493-498.

Chandra, S.D., Prasad, R.P., Bahadur, T.R., Kumar, S.S., and Bahadur, K.C.D. (2017). Allocative efficiency of resource use on beekeeping in chitwan district of Nepal. International Journal of Environment, Agriculture and Biotechnology, 2 (4): 14471451.

Chiedozie, E.C., Blessing, A., and Oliver, N. (2010). Resource use efficiency in arable crop production among smallholder farmers in Owerri agricultural zone of Imo State, Nigeria. Researcher, 2: 14-20.

Dickerson, G.W. (2004). Home garden strawberry production in new Mexico. Retrieved October 01, 2010 from http://aces.nmsu.edu/pubs/_h/h-324.pdf.

Gani, B.S., and Omonona, B.T. (2009). Resource use efficiency among small - scale irrigated maize producers in northern Taraba state of Nigeria. Journal of Human Ecology, 28 (2): 113-119.

Goni, M., Umar, A.S.S., and Usman, S. (2013). Analysis of resource-use efficiency in dry season vegetableproduction in Jere, Borno State, Nigeria. Journal of Biological Agricultural Healthcare, 3 (19): 18-23.

Ibitoye, S.J., Shaibu, U.M., and Omole, B. (2015). Analysis of resource use efficiency in tomato (Solanum lycopersicum) production in Kogi State, Nigeria. Asian Journal of Agricultural Extension, 6: 220-229.

Islam, M.S., Rahman, K.M.M., and Hasan, M.K. (2011). Profitability and resource use efficiency of producing major spices in Bangladesh. Bangladesh Journal of Agricultural Economics, XXXIV( 1\&2): 1-13

Jhingan, M.L. (2007). Micro Economic Theory. $6^{\text {th }}$ Edition, Vrinda Publications Ltd, India.

Khandoker, S., Uddin, M.T., Khatun, M., and Talukder, M.A.Z. (2014). Resource use efficiency and problems of commercial floriculture in selected areas in Bangladesh. International Journal of Biological Research, 16 (02): 20-26. 
Khatun, M., Rashid, M.A.,Miah, M.A.M., Khandoker, S. and Islam, M.T. (2017). Profitability of sandbar cropping method of pumpkin cultivation in char land areas of northern Bangladesh. Bangladesh Journal of Agricultural Research, 42(4): 647-663.

Majumder, M.K., Mozumdar, L., and Roy, P.C. (2009). Productivity and resource use efficiency of boro rice production. Journal of Bangladesh Agricultural University, 7(2): 247-252

Mari, F.M. (2009). Structure and efficiency analysis of vegetable production and marketing in Sindh, Pakistan.Ph. D thesis. Department of Agricultural Economics, Sindh Agriculture University, Tando Jam, Pakistan.

Mbata, J.N., and Matewa, J.C. (1983). Resource use efficiency among small-scale farmers in selected areas of western Kenya. Trpenlandwirt, Germany, Vol. 94 (2).

Miah, M.A.K., Alam, A.K.M.A., and Rahman, A.H.M.A. (2006). Impact of agricultural credit on $\mathrm{mv}$ boro rice cultivation in Bangladesh. Journal of Agriculture \& Rural Development, 4(1\&2), 161-168.

Mijindadi, N.B. (1980). Production efficiency on farms in northern Nigeria. Ph. D. Thesis, Unpublished, University of Cornell.

Olomla, A. (1991). Capture fisheries and aquaculture in Nigeria: A comparative economic analysis, issues in African Rural Development, Vol. 1, Winrock Institute for Agricultural Development.

Rahman, S. (2017). Resource use efficiency under self-selectivity: the case of Bangladeshi rice producers. The Australian Journal of Agricultural and Resource Economics, 55: 273-290.

Salami, P., Ahmadi, H., and Keyhani, A. (2010). Energy use and economic analysis of strawberryproduction in Sanandajzone of Iran. Biotechnology Agronomy Society and Environment, 14(4), 653-658.

Sarker, B., Majumder, S., and Sayem, S.M. (2018). Resource-use efficiency in watermelon production in the Patuakhali district, Bangladesh. Asian Journal of Agricultural and Horticultural Research, 1(3): 1-8.

Shrestha, R.B., Huang, W., and Pradhan, U. (2015).Resource use efficiency in vegetable production in the high hills of eastern Nepal. Nepalese Journal of Agricultural Economics, 2 (3): 79-87.

Sujan, H.K., Islam, F., Kazal, M.H., and Mondal, R.K. (2017a). Profitability and resource use efficiency of potato cultivation in Munshiganj district of Bangladesh. SAARC Journal of Agriculture, 15(2): 193-206.

Sujan, M.H.K., Islam, F., Azad, M.J., and Rayhan, S.J. (2017b). Financial profitability and resource use efficiency of boro rice cultivation in some selected area of Bangladesh. African Journal of Agricultural Research, 12(29): 2404-2411.

Umar, A.S.S., and Abdulkadir, M.B. (2015). Analysis of resource-use efficiency and productivity of residual soil moisture tomato production in Kadunastate, Nigeria. International Letters of Social and Humanistic Sciences 51: 152-157. 